\title{
Study on the Biodegradability of Organometallic Modifier Used in Liquid Fuel Combustion
}

\author{
Joanna Guziałowska-Tic*, Wilhelm Jan Tic \\ Department of Environmental Engineering, Opole University of Technology, \\ 5 Mikołajczyka, 45-271 Opole, Poland
}

Received: 11 August 2015

Accepted: 7 March 2016

\begin{abstract}
Our objective in this study was to assess the biodegradability and to calculate the percentage degradation for the modifier used in liquid fuel combustion processes and for sodium acetate (the reference material). We performed an assessment study evaluating high biodegradability in an aqueous environment using the manometric respirometry method (according to the OECD 301F guideline). Based on the results, it was found that the biodegradation of the test material reached $62.18 \%$ at the end of testing (after 28 days). On the other hand, the biodegradation of the reference material was at $85.94 \%$ at the end of our tests.
\end{abstract}

Keywords: ecotoxicological studies, biodegradability, iron-based modifier, combustion of liquid fuels

\section{Introduction}

The amount of organic compounds emitted to the environment has significantly increased in recent years. As a consequence, we have seen the development of research methods and monitoring of biodegradation processes, while providing the essential knowledge on undertaking decisions related to environmental protection. Substantially, there has been a focus on the biodegradability of organic compounds in an aqueous environment [1].

Biodegradation is the susceptibility of the compound to biochemical degradation by micro-organisms. In most cases, the compounds are completely destroyed and ultimately they are converted from relatively complex compounds into carbon dioxide, water and inorganic salts. Although the biodegradation is considered as a degradation to simple inorganic compounds, there can

*e-mail: j.guzialowska@po.opole.pl also arise more complex or more dangerous chemicals [2]. Natural chemical substances that occur in nature are often easily degradable; on the other hand, man-made organic substances are in many cases sparingly degradable. In an aqueous medium such substances can stay a long time, even for many years.

The primary objective of the biodegradation test is to assess the susceptibility of individual organic compounds and their mixtures on microbial decomposition.

Pursuant to the regulation by the minister of health on the criteria and mode of classification of chemical substances and mixtures [3], substances and mixtures are considered to be easily degradable if the following criteria are satisfied. Firstly, after biodegradation testing lasting for 28 days, the level of degradation reaches $70 \%$ for tests based on designations on dissolved organic carbon and degradation at the level of $60 \%$ for tests based on oxygen loss or carbon dioxide generation. Secondly, in the case of data given explicitly on the size of COD and BOD5, a substance or mixture shall be considered as easily degradable if the ratio of BOD5 to COD is greater 
than or equal to 0.5 . Furthermore, a substance or mixture is considered easily degradable when other convincing scientific evidence confirms that it can be biotically or abiotically degraded in an aquatic environment within 28 days by exceeding the level of $70 \%$.

Low biodegradability in water does not necessarily mean that the test product is not biodegradable. Application of selected strains of micro-organisms allows for obtaining a high degree of distribution even of these substances, which are in fact very difficult for biodegradation. Second, the medium in which the research tests are carried out is a very important factor affecting biodegradability, and the conditions under which the sample is located [4].

\section{Test Material}

In order to reduce emissions of harmful products of liquid fuel combustion processes into the atmosphere, it is required to use specific modifiers. One of the types is organic salts of metals being soluble in fuel, which form oxides of metals to improve the oxidizing properties of fuels in conditions of combustion processes. The product discussed in research is the reaction mass of soaps and salts of iron (III) generated in the production process, creating stable emulsion in the organic solvent - fuel oil [5].

The metal catalyst was obtained from salt of $\mathrm{Fe}^{3+}$ soluble in water. At the stage of the first synthesis, a mixture of iron hydroxide (III) and ammonium hydroxide was prepared, which then reacts with fatty acids dissolved in diesel oil. After the reaction, the organic phase was separated from the aqueous phase. The organic phase containing ammonium soaps and metal hydroxides in fuel oil is considered a catalyst.

In the case of high concentrations of iron in fuel oil $\left(100 \mathrm{~g} \mathrm{Fe} / \mathrm{dm}^{3}\right)$, it is required that approximately $25 \%$ of iron occurs in the form of ammonium soaps, while the remaining part of the metal occurring in the form of hydroxide is suspended in the solvent as a colloid.

The threat from fuel additives is related to the presence of organic iron salts in their composition and the petroleumderived solvents they are dissolved in. The risk of soil and water contamination with iron modifier occurs at the stage of its manufacture, storage, and addition to fuel.

In terms of water contamination with iron compounds, it was ascertained that the toxicity of this element is particularly distinct in higher concentrations. In this case, the contaminants are quickly absorbed by the gastrointestinal tract, which may be harmful for the organisms living in a particular aquatic environment $[6,7]$.

Moreover, uncontrolled leakage of a petroleumderived substance may substantially interfere with a soil and water environment. Hydrocarbons hinder gas exchange, limit light, reduce the concentration of oxygen, degrade groundwaters, contaminate soil and ground, and above all are toxic, mutagenic, and carcinogenic to all organisms [8].
In the future, it is planned to launch iron modifier production of more than $100 \mathrm{Mg}$ per year; therefore, it is required, among others, to perform tests on toxicological and ecotoxicological properties required for product registration in the REACH system $[9,10]$. Research tests necessary to assess the risks to human health and hazards to environment were performed in accordance with the principles of good laboratory practice in the Institute of Organic Industry in Pszczyna $[11,12]$. We conducted eight toxicological tests and 10 ecotoxicological tests on the basis of production volumes and the data contained in annexes VII-IX of the REACH regulation [13].

In turn, physicochemical research tests on the ironbased modifier of combustion in liquid fuels were conducted in accordance with the methodology entered in commission regulation (EC) No 440/2008 laying down test methods complying with the REACH regulation [14]. Table 1 summarizes results of basic physicochemical properties of iron-based modifier during combustion in liquid fuels.

Our paper presents the results of biodegradability according to the OECD 301 guideline for the discussed iron-based modifier of combustion processes in liquid fuels.

\section{Experimental Procedures}

We performed an assessment study on high susceptibility of the test material (iron-based modifier) on biodegradation in the aquatic environment using the manometric respirometry method in accordance with the OECD 301 guideline [19]. This method is suitable for a wide range of substances, and due to continuous mixing process, testing the substance was kept at a constant level throughout the entire period of the studies [4]. The study was conducted in BOD bottles, in which appropriate volumes of mineral nutrient solution, microbial inoculum,

Table 1. Results of physicochemical tests.

\begin{tabular}{|c|c|c|}
\hline Type of test & Result & Unit \\
\hline $\begin{array}{c}\text { Physical state at } 20^{\circ} \mathrm{C} \text { and } \\
\text { pressure of } 101.3 \mathrm{kPa}\end{array}$ & liquid & - \\
\hline Boiling point according to [14] & $277 \pm 22$ & ${ }^{\circ} \mathrm{C}$ \\
\hline Relative density by [15] & $0.9071 \pm 0.001$ & $\mathrm{~g} / \mathrm{cm}^{3}$ \\
\hline $\begin{array}{l}\text { Solubility in water by }[16] \\
\text { at a temperature of } 20^{\circ} \mathrm{C} \pm 0.5\end{array}$ & $\begin{array}{c}\text { base oil: } \\
132.3 \\
\text { iron salt: } 47.6\end{array}$ & $\mathrm{mg} / \mathrm{dm}^{3}$ \\
\hline $\begin{array}{l}\text { Distribution coefficient of n- oc- } \\
\text { tanol / water according to [14] }\end{array}$ & \multicolumn{2}{|c|}{ no marking } \\
\hline Flash point according to [16] & $94 \pm 2$ & ${ }^{\circ} \mathrm{C}$ \\
\hline $\begin{array}{l}\text { Auto-ignition temperature } \\
\text { according to [17] }\end{array}$ & $\begin{array}{c}250( \pm 6) \\
\mathrm{p}=990.5 \mathrm{hPa}\end{array}$ & ${ }^{\circ} \mathrm{C}$ \\
\hline $\begin{array}{c}\text { Kinematic viscosity by [18] } \\
\text { at } 20^{\circ} \mathrm{C}\end{array}$ & 11.89 & $\mathrm{~mm}^{2} / \mathrm{s}$ \\
\hline
\end{tabular}


and sodium acetate (or a proper test portion of the test material) were provided. The concentration of the test material and sodium acetate used in the experiment equaled $100 \mathrm{mg} / \mathrm{dm}^{3}$. The results were read out using the Sensomat system, after the period of 1, 3, 5, 7, 14, 21, and 28 days from the beginning of the experimental tests.

\section{Testing Procedure and Conditions}

Activated sludge derived from the biological wastewater treatment plant was used as a microbial inoculum. The activated sludge was downloaded from the aeration tank into plastic containers and transported to the laboratory. Immediately after it was transported, the activated sludge was poured through a sieve having a mesh size of $1 \mathrm{~mm}$; it was decanted and washed three times with tap water and mineral medium. After these treatments, the sludge was intensively aerated. At the same time, two sediment samples (of $50 \mathrm{~cm}^{3}$ each) were downloaded in order to determine the dry matter in accordance with the BS EN 12880: 2004 [20]. We used $20 \mathrm{mg} / \mathrm{dm}^{3}$ dry mass of sludge.

Table 2 shows composition of the medium used in the experimental tests.

Each of the solutions from (a) to (d) were dissolved in water and made up to $1 \mathrm{dm}^{3}$. All the above solutions were mixed in the following proportions: $10 \mathrm{~cm}^{3}$ of the solution (a) was mixed with $800 \mathrm{~cm}^{3}$ of deionized water, and then $1 \mathrm{~cm}^{3}$ of solutions (b), (c), and (d) were each added. All of this was supplemented with water to the level of $1 \mathrm{dm}^{3}$.

\section{Determining Chemical Oxygen Demand}

Before performing the experiment test to assess the high biodegradability of the test material and reference material method in the aquatic environment using manometric respirometry, chemical oxygen demand

Table 2. The composition of the medium used in the experimental tests.

\begin{tabular}{|c|c|c|}
\hline Solution & Substance & $\begin{array}{c}\text { Concentration } \\
{\left[\mathrm{g} / \mathrm{dm}^{3}\right]}\end{array}$ \\
\hline \multirow{4}{*}{$a$} & $\begin{array}{c}\text { Monobasic potassium } \\
\text { dihydrogen phosphate - } \\
\mathrm{KH}_{2} \mathrm{PO}_{4}\end{array}$ & 8.50 \\
\hline & $\begin{array}{l}\text { Dipotassium monohydrogen } \\
\text { orthophosphate }-\mathrm{K}_{2} \mathrm{HPO}_{4}\end{array}$ & 21.75 \\
\hline & $\begin{array}{l}\text { Disodium monohydrogen } \\
\text { phosphate dihydrate - } \\
\mathrm{Na}_{2} \mathrm{HPO}_{4} \cdot 2 \mathrm{H}_{2} \mathrm{O}\end{array}$ & 33.40 \\
\hline & Ammonium chloride $-\mathrm{NH}_{4} \mathrm{Cl}$ & 0.50 \\
\hline$b$ & Calcium chloride $-\mathrm{CaCl}_{2}$ & 27.50 \\
\hline$c$ & $\begin{array}{c}\text { Magnesium sulfate } \\
\text { heptahydrate }-\mathrm{MgSO}_{4} \cdot 7 \mathrm{H}_{2} \mathrm{O}\end{array}$ & 22.50 \\
\hline$d$ & $\begin{array}{c}\text { Iron (III) chloride xehahydrate } \\
-\mathrm{FeCl}_{3} \cdot 6 \mathrm{H}_{2} \mathrm{O}\end{array}$ & 0.25 \\
\hline
\end{tabular}

(COD) was designated. Designation of COD was made using dichromate based on the ISO 6060: 2006 standard [21]. This value is needed to calculate the percentage distribution of the test and reference materials.

Designation of (COD) by dichromate method consists of determining the number of milligrams of potassium dichromate, calculated on the amount of oxygen being consumed in the oxidation process of the test compound dissolved in water. The oxidation is carried out in a sulfuric acid medium in the presence of silver sulfate as a catalyst. For designation purposes, relevant test portions of the test material (two samples at concentrations of $100 \mathrm{mg} / \mathrm{dm}^{3}$ ), the reference material solution $\left(100 \mathrm{mg} / \mathrm{dm}^{3}\right)$, and a blank sample were used. Each sample was prepared twice. COD was determined immediately after the samples were prepared.

\section{Experimental Testing}

In the research test, six BOD bottles were used. Bottles 1 and 2 contained the test material and inoculum of microorganisms. In turn, bottles 3 and 4 explicitly contained inoculum - a blank sample (BS). Bottle No. 5 contained a reference material (sodium acetate) and inoculum of micro-organisms, whereas No. 6 contained the test material, the reference material (sodium acetate), and inoculum of micro-organisms for toxicity control (Table 3).

Before proceeding to the experiment, the $\mathrm{pH}$ of each solution and mineral nutrient solution were measured, which amounted to 7.30. Adequate volumes of the basic solutions of test material (bottles 1, 2, and 6), of the reference material (bottles 5 and 6), and of the mineral medium (all bottles) were introduced into the BOD bottle and placed in a thermostatic cabinet. Once the solutions reach the desired temperature $\left(22^{\circ} \mathrm{C}\right)$, their contents were inoculated with activated sludge in such a manner that the concentration of solid particulates in mixtures being tested was $20 \mathrm{mg}$ per $\mathrm{dm}^{3}$. Each bottle was placed on a magnetic stirrer, and $45 \%$ of potassium hydroxide solution was applied as $\mathrm{CO}_{2}$ absorber.

The following criteria should be fulfilled for the test to be recognized as credible:

- Oxygen uptake by a blank sample should not be higher than $60 \mathrm{mg}$ per $\mathrm{dm}^{3}$ within the testing period of 28 days, whereas oxygen uptake by the test material should exceed the amount of $60 \mathrm{mg}$ per $\mathrm{dm}^{3}$ within the testing period of 28 days.

- The distribution of toxicity covering both the test substance and the reference substance within 14 days should be higher than $25 \%$.

- The $\mathrm{pH}$ at the end of the experiment should be in the range of 6-8.5.

However, if the $\mathrm{pH}$ value at the end of testing is not within the limits stated above, and simultaneously the oxygen consumption by the test substance is less than $60 \%$, the test should be repeated using a lower concentration of test substance [17]. 
Table 3. The $\mathrm{pH}$ value in the tested bottles.

\begin{tabular}{|c|c|c|}
\hline BOD bottle & $\begin{array}{c}\mathrm{pH} \text { value } \\
\text { (on day 0) }\end{array}$ & $\begin{array}{c}\mathrm{pH} \text { value } \\
\text { (on 28. day) }\end{array}$ \\
\hline B1 (blank) & 7.55 & 7.48 \\
\hline B2 (blank) & 7.57 & 7.45 \\
\hline RM (reference material) & 7.28 & 7.18 \\
\hline TC (toxicity control) & 7.61 & 7.55 \\
\hline TM1 (test material) & 7.58 & 7.55 \\
\hline TM1 (test material) & 7.63 & 7.58 \\
\hline
\end{tabular}

\section{Test Results}

Biochemical oxygen demand (BOD) - the amount of oxygen consumed by micro-organisms for metabolic processes of chemical compounds - was computed on the basis of the obtained test results, according to the following formula:

$$
\begin{gathered}
B O D=\frac{m g \mathrm{O}_{2} \text { uptake by test material }-m g \mathrm{O}_{2} \text { uptake by blank }}{m g \text { test item in vessel }}= \\
=m g \mathrm{O}_{2} / \mathrm{mg} \text { test material }
\end{gathered}
$$

In turn, the percentage degradation of the test material and of the reference material were calculated based on the following formula:

$\%$ degradation $=\frac{B O D\left(\mathrm{mg} \mathrm{O}_{2} / \mathrm{mg} \text { test material }\right)}{\text { ThOD or } \operatorname{COD}\left(\mathrm{mg} \mathrm{O}_{2} / m g \text { test material }\right)} \times 100$ ...where ThOD is theoretical oxygen demand, calculated based on the molecular formula of the substance, meaning the total amount of oxygen required for oxidation of a chemical compound; and COD is chemical demand on oxygen - the amount of oxygen being consumed during oxidation of the test compound using a hot acidified solution of potassium dichromate.

Due to the molecular structure of the test material, the content of nitrate and nitrite in the samples containing the test material were not analyzed at the beginning and at the end of the experiment. In the final calculation, the correction for nitrification was not considered in this case.

\section{Results}

All of the above-mentioned reliability criteria have been fulfilled in the conducted study on biodegradability. Table 3 summarizes the results of $\mathrm{pH}$ measurements for all samples tested on day 0 and all through until the $28^{\text {th }}$ day of the experiment. At the beginning of the research test, the level of $\mathrm{pH}$ varied between 7.28 and 7.63; and at the end of the trail, it was in the range from 7.18 to 7.58 . In turn, the average oxygen consumption and biochemical oxygen demand (BOD) on days $0,3,5,7,14,21$, and 28 of the analysis for the test material, the reference material and the control of toxicity are presented in Tables 4-6. For the test material, BOD ranged from $0.006 \mathrm{mg} \mathrm{O}_{2}$ per $\mathrm{dm}^{3}$ in the third day of the experiment to $\mathrm{O}_{2}$ value of $0.36 \mathrm{mg}$ per $\mathrm{dm}^{3}$ in the final day of the test study (Table 4-6). Whereas for the reference material, $\mathrm{BOD} \mathrm{O}_{2}$ value ranged from $0.157 \mathrm{mg}$ per $\mathrm{dm}^{3}$ on the first day of the experiment, and on the final day of the study $\mathrm{O}_{2}$ was of $0.660 \mathrm{mg}$ per $\mathrm{dm}^{3}$ (Table. 5). As for the control of toxicity, the biochemical demand on oxygen in the first day of the experiment amounted to $0.157 \mathrm{mg}$ of $\mathrm{O}_{2}$ per $\mathrm{dm}^{3}$; and the highest value was set out on the seventh day of the

\begin{tabular}{|c|c|c|c|c|c|c|}
\hline Day & Sample & $\begin{array}{l}\text { The average } \\
\text { uptake of } \mathrm{O}_{2} \\
{\left[\mathrm{mg} \mathrm{O}_{2} / \mathrm{dm}^{3}\right]}\end{array}$ & Sample & $\begin{array}{l}\text { Uptake of } \mathrm{O}_{2} \\
{\left[\mathrm{mg} \mathrm{O}_{2} / \mathrm{dm}^{3}\right]}\end{array}$ & $\begin{array}{c}\mathrm{O}_{2} \text { uptake by test material, corrected } \\
\text { for average power consumption of } \mathrm{O}_{2} \\
\text { by blank sample } \\
{\left[\mathrm{mg} \mathrm{O}_{2} / \mathrm{dm}^{3}\right]}\end{array}$ & $\begin{array}{l}\mathrm{BOD} \\
{\left[\mathrm{mg} \mathrm{O}_{2} / \mathrm{dm}^{3}\right.} \\
\mathrm{mg} \text { of the test } \\
\text { material }]\end{array}$ \\
\hline 1 & $\begin{array}{l}\text { B1 } \\
\text { B2 }\end{array}$ & 11.3 & $\begin{array}{l}\text { TM1 } \\
\text { TM2 }\end{array}$ & $\begin{array}{l}12.0 \\
13.5 \\
\end{array}$ & $\begin{array}{l}0.7 \\
2.2 \\
\end{array}$ & $\begin{array}{l}0.007 \\
0.022 \\
\end{array}$ \\
\hline 3 & $\begin{array}{l}\text { B1 } \\
\text { B2 }\end{array}$ & 19.0 & $\begin{array}{l}\text { TM1 } \\
\text { TM2 }\end{array}$ & $\begin{array}{l}25.0 \\
25.0 \\
\end{array}$ & $\begin{array}{l}6.0 \\
6.0 \\
\end{array}$ & $\begin{array}{l}0.060 \\
0.060 \\
\end{array}$ \\
\hline 5 & $\begin{array}{l}\text { B1 } \\
\text { B2 }\end{array}$ & 26.5 & $\begin{array}{l}\text { TM1 } \\
\text { TM2 }\end{array}$ & $\begin{array}{l}41.0 \\
41.0\end{array}$ & $\begin{array}{l}14.5 \\
14.5\end{array}$ & $\begin{array}{l}0.145 \\
0.145\end{array}$ \\
\hline 7 & $\begin{array}{l}\text { B1 } \\
\text { B2 }\end{array}$ & 32.0 & $\begin{array}{l}\text { TM1 } \\
\text { TM2 }\end{array}$ & $\begin{array}{l}52.0 \\
47.0 \\
\end{array}$ & $\begin{array}{l}20.0 \\
15.5 \\
\end{array}$ & $\begin{array}{l}0.200 \\
0.150\end{array}$ \\
\hline 14 & $\begin{array}{l}\text { B1 } \\
\text { B2 }\end{array}$ & 46.0 & $\begin{array}{l}\text { TM1 } \\
\text { TM2 }\end{array}$ & $\begin{array}{l}76.0 \\
67.0\end{array}$ & $\begin{array}{l}30.0 \\
21.0\end{array}$ & $\begin{array}{l}0.300 \\
0.210\end{array}$ \\
\hline 21 & $\begin{array}{l}\text { B1 } \\
\text { B2 }\end{array}$ & 47.5 & $\begin{array}{l}\text { TM1 } \\
\text { TM2 }\end{array}$ & $\begin{array}{l}82.0 \\
79.0\end{array}$ & $\begin{array}{l}34.5 \\
31.5\end{array}$ & $\begin{array}{l}0.345 \\
0.315\end{array}$ \\
\hline 28 & $\begin{array}{l}\text { B1 } \\
\text { B2 }\end{array}$ & 46.0 & $\begin{array}{l}\text { TM1 } \\
\text { TM2 }\end{array}$ & $\begin{array}{l}82.0 \\
81.0\end{array}$ & $\begin{array}{l}36.0 \\
35.0\end{array}$ & $\begin{array}{l}0.360 \\
0.350 \\
\end{array}$ \\
\hline
\end{tabular}

Table 4. The results obtained for the test material. 
Table 5. The results obtained for the reference material.

\begin{tabular}{|c|c|c|c|c|c|c|}
\hline Day & Sample & $\begin{array}{c}\text { The average } \\
\text { uptake of } \mathrm{O}_{2} \\
{\left[\mathrm{mg} \mathrm{O}_{2} / \mathrm{dm}^{3}\right]}\end{array}$ & Sample & $\begin{array}{c}\text { Uptake of } \mathrm{O}_{2} \\
{\left[\mathrm{mg} \mathrm{O}_{2} / \mathrm{dm}^{3}\right]}\end{array}$ & $\begin{array}{c}\mathrm{O}_{2} \text { uptake by test material, corrected } \\
\text { for average power consumption } \\
\text { of } \mathrm{O}_{2} \text { by blank sample } \\
{\left[\mathrm{mg} \mathrm{O}_{2} / \mathrm{dm}^{3}\right]}\end{array}$ & $\begin{array}{c}\mathrm{BOD} \\
{\left[\mathrm{mg}_{2} / \mathrm{dm}^{3} \mathrm{mg}\right.} \\
\text { of the test material] }\end{array}$ \\
\hline 1 & $\begin{array}{c}\mathrm{B} 1 \\
\mathrm{~B} 2\end{array}$ & 11.3 & $\mathrm{RM}$ & 27.0 & 31.5 & 0.157 \\
\hline 3 & $\begin{array}{l}\mathrm{B} 1 \\
\mathrm{~B} 2\end{array}$ & 19.0 & $\mathrm{RM}$ & 50.5 & 60.5 & 0.315 \\
\hline 5 & $\begin{array}{l}\mathrm{B} 1 \\
\mathrm{~B} 2\end{array}$ & 26.5 & $\mathrm{RM}$ & 87.0 & 65.0 & 0.605 \\
\hline 7 & $\begin{array}{l}\mathrm{B} 1 \\
\mathrm{~B} 2\end{array}$ & 32.0 & $\mathrm{RM}$ & 97.0 & 64.0 & 0.650 \\
\hline 14 & $\begin{array}{l}\mathrm{B} 1 \\
\mathrm{~B} 2\end{array}$ & 46.0 & $\mathrm{RM}$ & 110.0 & 62.5 & 0.640 \\
\hline 21 & $\begin{array}{l}\mathrm{B} 1 \\
\mathrm{~B} 2\end{array}$ & 47.5 & $\mathrm{RM}$ & 110.0 & 66.0 & 0.625 \\
\hline
\end{tabular}

test, and it reached the $\mathrm{O}_{2}$ value of $0.470 \mathrm{mg}$ per $\mathrm{dm}^{3}$ (Table 6).

Prior to the experiment being performed, the values of COD were also determined for the test material and the reference material. COD value for the test material was $0.571 \mathrm{mg}$ of $\mathrm{O}_{2}$ per $\mathrm{dm}^{3}$, while the $\mathrm{COD}$ value for the reference material was $0.768 \mathrm{mg} \mathrm{O}_{2} / \mathrm{dm}^{3}$ (the ThOD value for sodium acetate, based on the structural formula, amounted to $0.78 \mathrm{mg} \mathrm{O}_{2} / \mathrm{dm}^{3}$ ).

On the basis of the calculated values of COD and BOD (Tables 4-5), on the basis of formula (2), the biodegradability of the test material and a reference material, that is sodium acetate, was determined (Fig. 1).
The biodegradability for the control of toxicity is presented in Table 7, which is considered to be reliable due to the fact that the toxicity degradation covering both the test substance and the reference substance performed over 14 days exceeded $25 \%$.

\section{Discussion of the Results}

Table 4 shows consumption of $\mathrm{O}_{2}$ after days 1, 3, $5,7,14,21$, and 28 of the experiment measured for the control samples and the test material. The table also shows the calculated values of BOD $(\mathrm{mg} \mathrm{O}$, per mg of the test material) on different days; and then the biodegradation of

Table 6 . The results obtained for the control of toxicity.

\begin{tabular}{|c|c|c|c|c|c|c|}
\hline Day & Sample & $\begin{array}{l}\text { The average } \\
\text { uptake of } \mathrm{O}_{2} \\
{\left[\mathrm{mg} \mathrm{O}_{2} / \mathrm{dm}^{3}\right]}\end{array}$ & $\begin{array}{l}\text { Sam- } \\
\text { ple }\end{array}$ & $\begin{array}{l}\text { Uptake of } \mathrm{O}_{2} \\
{\left[\mathrm{mg} \mathrm{O}_{2} / \mathrm{dm}^{3}\right]}\end{array}$ & $\begin{array}{c}\mathrm{O}_{2} \text { uptake by toxicity control, } \\
\text { corrected for average power } \\
\text { consumption of } \mathrm{O}_{2} \text { by blank sample } \\
{\left[\mathrm{mg} \mathrm{O}_{2} / \mathrm{dm}^{3}\right]}\end{array}$ & $\begin{array}{l}\mathrm{BOD} \\
{\left[\mathrm{mg} \mathrm{O}_{2} / \mathrm{dm}^{3} \mathrm{mg} \text { of the }\right.} \\
\text { reference material / test } \\
\text { material }]\end{array}$ \\
\hline 1 & $\begin{array}{l}\mathrm{B} 1 \\
\mathrm{~B} 2\end{array}$ & 11.3 & $\mathrm{TC}$ & 27.0 & 15.7 & $\begin{array}{l}\text { RM } 0.157 \\
\text { TM } 0.157\end{array}$ \\
\hline 3 & $\begin{array}{l}\text { B1 } \\
\text { B2 }\end{array}$ & 19.0 & $\mathrm{TC}$ & 49.5 & 30.5 & $\begin{array}{l}\text { RM } 0.305 \\
\text { TM } 0.305\end{array}$ \\
\hline 5 & $\begin{array}{l}\mathrm{B} 1 \\
\mathrm{~B} 2\end{array}$ & 26.5 & $\mathrm{TC}$ & 52.0 & 25.5 & $\begin{array}{l}\text { RM } 0.255 \\
\text { TM } 0.255\end{array}$ \\
\hline 7 & $\begin{array}{l}\mathrm{B} 1 \\
\mathrm{~B} 2 \\
\end{array}$ & 32.0 & $\mathrm{TC}$ & 79.0 & 47.0 & $\begin{array}{l}\text { RM } 0.470 \\
\text { TM } 0.470\end{array}$ \\
\hline 14 & $\begin{array}{l}\mathrm{B} 1 \\
\mathrm{~B} 2\end{array}$ & 46.0 & $\mathrm{TC}$ & 87.0 & 41.0 & $\begin{array}{l}\text { RM } 0.410 \\
\text { TM } 0.410\end{array}$ \\
\hline 21 & $\begin{array}{l}\text { B1 } \\
\text { B2 }\end{array}$ & 47.5 & $\mathrm{TC}$ & 87.0 & 39.5 & $\begin{array}{l}\text { RM } 0.395 \\
\text { TM } 0.395\end{array}$ \\
\hline 28 & $\begin{array}{l}\text { B1 } \\
\text { B2 }\end{array}$ & 46.0 & $\mathrm{TC}$ & 92.0 & 46.0 & $\begin{array}{l}\text { RM } 0.460 \\
\text { TM } 0.460\end{array}$ \\
\hline
\end{tabular}




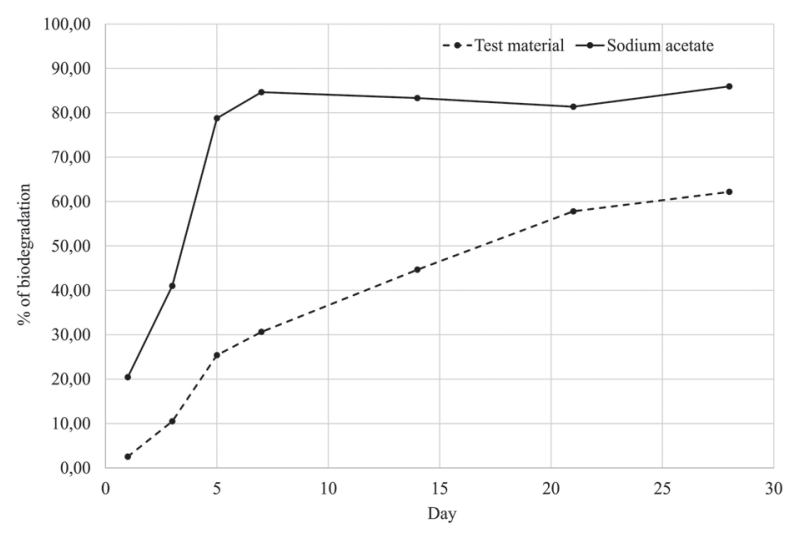

Fig. 1. Percentage of the distribution of reference material and test material in subsequent days of the experiment.

Table 7. The percentage of distribution for the control of toxicity.

\begin{tabular}{|c|c|c|}
\hline Day & \% of RM degradation & \% of TM degradation \\
\hline 1 & 20.44 & 27.50 \\
\hline 3 & 39.71 & 53.42 \\
\hline 5 & 33.20 & 44.66 \\
\hline 7 & 61.20 & 82.31 \\
\hline 14 & 53.39 & 71.80 \\
\hline 21 & 51.43 & 69.18 \\
\hline 28 & 59.90 & 80.56 \\
\hline
\end{tabular}

iron-based modifier was calculated (Fig. 1). Based on the obtained results for the test material, it was concluded that its biodegradation on day 7 amounted to $30.65 \%$, on day 14 to $44.66 \%$, on day 21 to $57.80 \%$, and to $62.18 \%$ on the last day of the experiment. Pursuant to the regulation of the minister of health on the criteria and classification of chemical substances and mixtures [3], it can be concluded that iron-based modifier is easily degradable in an aquatic environment because a level of $60 \%$ degradation was exceeded in tests based on oxygen loss.

For comparison, sodium acetate was used as the reference substance, which satisfies the criteria for high biodegradability. Table 5 shows the measured uptake of $\mathrm{O}_{2}$ after days $1,3,5,7,14,21$, and 28 of the experiment for the control samples and the reference material. In addition, the table shows calculated values of BOD (mg $\mathrm{O}_{2} / \mathrm{mg}$ of reference material) on particular days. Based on the results obtained for the reference material, it was stated that its biodegradation in day 7 was $84.64 \%$, on day $1483.33 \%$, on day $2181.38 \%$, and $85.94 \%$ on the last day of the experiment.

\section{Conclusions}

Based on analysis of the test results on biodegradability carried out using the manometric respirometry test method, it can be concluded that iron modifier is easily degradable in water environment due to the fact that after 28 days of experimental studies its biodegradability exceeded $60 \%$. This means that, in accordance with the regulation of the minister of health on criteria and mode of classification of chemical substances and mixtures [3], iron modifier is safe for aquatic environments.

\section{Acknowledgements}

Our work was performed within the framework of the Innovative Economy Operational Program 2007-13 (No. POIG.01.04.00-16-159/12).

\section{References}

1. BALLESTEROS M.M., GARCIA B.E, ORTEGA-GOMEZ E., SÁNCHEZ-PÉREZ J.A. A new bioseed for determination of wastewater biodegradability: analysis of the experimental procedure. Environ. Sci. Pollut. Res. 21, 9522, 2014.

2. HOFFMAN D.J., RATTNER B.A., BURTON G.A. Jr., CAIRNS J. Jr. Handbook of Ecotoxicology, $2^{\text {nd }}$ Ed.; Lewis Publishers, Boca Ranton, 2002.

3. Regulation of the Minister of Health of 10 August 2012 on the criteria and methods for the classification of chemical substances and mixtures. Poland's Journal of Laws of 2012, Item 1018 [In Polish].

4. GĘBALA P., MICKIEWICZ A. Spinosad - ready biodegradability test in water. J. Ecol. Health 16 (2), 55, 2012 [In Polish].

5. TIC W.J. Metal Salts as the Homogeneous Catalysts for an Effective Combustion of Liquid Fuels. Pol. J. Environ. Stud. 17 (3), 439, 2008.

6. BABY J., RAJ J.S., BIBY E.T, SANKARGANESH P., JEEVITHA M.V., AJISHA S.U., RAJAN S.S. Toxic effect of heavy metals on aquatic environment. Int. J. Biol. Chem. Sci. 4 (4), 939, 2010.

7. ZEITOUN M.M., MEHANA E.E. Impact of Water Pollution with Heavy Metals on Fish Health: Overview and Updates. Global Veterinaria. 12 (2), 219, 2014.

8. PIEKUTIN J. Organic pollution in ground water. Inż. ekol. 26, 95, 2011 [In Polish].

9. Regulation (EC) of the European Parliament and of the Council, on the Registration, Evaluation, Authorisation and Restriction of Chemicals (REACH); No 1907/2006 of 18 December 2006.

10. GUZIAŁOWSKA-TIC J., TIC W. J. Current requirements for the registration of products under the REACH system using an example of ecological solvents. Chemik 65 (11), 1204, 2011.

11. Directive 2004/10/EC of the European Parliament and of the Council of February 11, 2004 on the harmonization of laws, regulations, and administrative provisions relating to the application of the principles of Good Laboratory Practice and the verification of their applications for tests on chemical substances (codified version).

12. Polish regulation: Regulation of the Minister of Health of May 22, 2013 on Good Laboratory Practice and conducting studies in compliance with the principles of Good Laboratory Practice (Poland's Journal of Laws No 108, Item 665) [In Polish].

13. GUZIAŁOWSKA-TIC J. Selected toxicological and 
ecotoxicological properties of additive for combustion of liquid fuels. Chemik 68 (10), 831, 2014.

14. Council Regulation (EC) No 440/2008 of 30 May 2008 laying down test methods pursuant to Regulation (EC) No 1907/2006 of the European Parliament and of the Council on the Registration, Evaluation, Authorization, and Restriction of Chemicals (REACH). Part V. Manometric respirometry test (Method C. $4-\mathrm{D})$.

15. OECD Guidelines for the Testing of Chemicals: NF T 20-053:1985. „Chemical products for industrial use -Determination of density of solids in powder and liquids. Pycnometric method".

16. PN-EN ISO 2592: 2008. „Petroleum products Determination of flash and fire points - Cleveland open cup method" [In Polish].
17. DIN 51794:05.2003. „Determining the ignitron temperature of petroleum products".

18. PN-EN ISO 3104:2004. "Petroleum products. Transparent and opaque liquids. Determination of kinematic viscosity and calculation of dynamic viscosity EQP". OECD Method No 114 [In Polish].

19. OECD Guideline for the Testing of Chemicals No. 301F (1992): "Ready biodegradability, manometric respirometry test".

20. PN - ISO 6060: 2006 Water quality. Determination of chemical oxygen demand [In Polish].

21. PN - EN 12880: 2004 Activated sludge - Determination of dry weight and water content [In Polish]. 